\title{
Flow of Antarctic Bottom water from the Vema Channel
}

\author{
Eugene G. Morozov ${ }^{*}$ (D), Dmitry I. Frey and Roman Y. Tarakanov
}

\begin{abstract}
We analyze measurements of bottom currents and thermohaline properties of water north of the Vema Channel with the goal to find pathway continuations of Antarctic Bottom Water flow from the Vema Channel into the Brazil Basin. The analysis is based on CTD/LADCP casts north of the Vema Channel. The flow in the deep Vema Channel consists of two branches. The deepest current flows along the bottom in the center of the channel and the other branch flows above the western wall of the channel. We found two smaller channels of the northern continuation of the deeper bottom flow. These flows become weak and almost disappear at a latitude of $25^{\circ} 30^{\prime} \mathrm{S}$. The upper current flows at a depth of 4100-4200 $\mathrm{m}$ along the continental slope. We traced this current up to $24^{\circ} \mathrm{S}$ over a distance exceeding $250 \mathrm{~km}$. This branch transports bottom water that eventually fills the deep basins of the North Atlantic.
\end{abstract}

Keywords: Vema channel, Abyssal currents, Antarctic bottom water, CTD/LADCP profiles, Bottom layer

\section{Introduction}

The Rio Grande Rise separates the Argentine and Brazil basins. It is a topographic obstacle for bottom water propagation to the north. The Vema Channel is a pathway of Antarctic Bottom Water (AABW, potential temperature $\theta<2{ }^{\circ} \mathrm{C}$ ) flow to the north over the Rio Grande Rise (Fig. 1). The depths of the Vema Channel exceed $4600 \mathrm{~m}$ compared with the background depths of $4200 \mathrm{~m}$ (Hogg et al. 1999; Speer and Zenk 1993).

Repeated measurements of temperature, salinity, and velocity at hydrographic stations confirm the prominent role of the Vema Channel for the transport of AABW compared with the Hunter Channel in the east and over the Santos Plateau in the west. The $\theta=2{ }^{\circ} \mathrm{C}$ potential temperature isotherm divides large-scale North Atlantic and Antarctic origin flows directed southward and northward, respectively. The transport of AABW through the repeated transect along $31^{\circ} \mathrm{S}$ in the Vema Channel based on LADCP (Lowered Acoustic Doppler Profiler) and mooring measurements ranges between 1.6 and $3.5 \mathrm{~Sv}$ (Morozov et al. 2010). However, not all the water that

\footnotetext{
*Correspondence: egmorozov@mail.ru

Shirshov Institute of Oceanology, Russian Academy of Sciences,

Nakhimovsky 36, Moscow 117997, Russia
}

flows through this section at $31^{\circ} \mathrm{S}$ reaches the northern part of the channel at $27^{\circ} \mathrm{S}$.

The existence of two cores of AABW flow in the Vema Channel was reported in (Tarakanov and Morozov 2015; Tarakanov et al. 2020). The research made in (Tarakanov et al. 2020) is related to the study of hydrodynamic properties of the bottom flow and underwater spillways. Another study is related to numerical simulations of the flow in the Vema Channel including the region north of the channel (Frey et al. 2019); however, direct measurements of the velocities and thermohaline structure of these bottom flows remain rare.

The objective of this paper is to study the pathways of propagation of the coldest and densest AABW $\left(\theta<0.0{ }^{\circ} \mathrm{C}\right)$ into the Brazil Basin north of the Rio Grande Plateau based on the CTD (conductivity-temperature-depth) and LADCP measurements. The main goal is to locate these pathways geographically. We used the Sea-Bird-19plus and RDI Sentinel $300 \mathrm{kHz}$ instruments. We traced the flow by finding the coldest temperatures at the bottom and by measuring velocities in the cold water flows using LADCP. We also took into consideration that the bottom flow should either follow the isobaths or descend.
Springer Open

(c) The Author(s) 2020. This article is licensed under a Creative Commons Attribution 4.0 International License, which permits use, sharing, adaptation, distribution and reproduction in any medium or format, as long as you give appropriate credit to the original author(s) and the source, provide a link to the Creative Commons licence, and indicate if changes were made. The images or other third party material in this article are included in the article's Creative Commons licence, unless indicated otherwise in a credit line to the material. If material is not included in the article's Creative Commons licence and your intended use is not permitted by statutory regulation or exceeds the permitted use, you will need to obtain permission directly from the copyright holder. To view a copy of this licence, visit http://creativeco mmons.org/licenses/by/4.0/. 


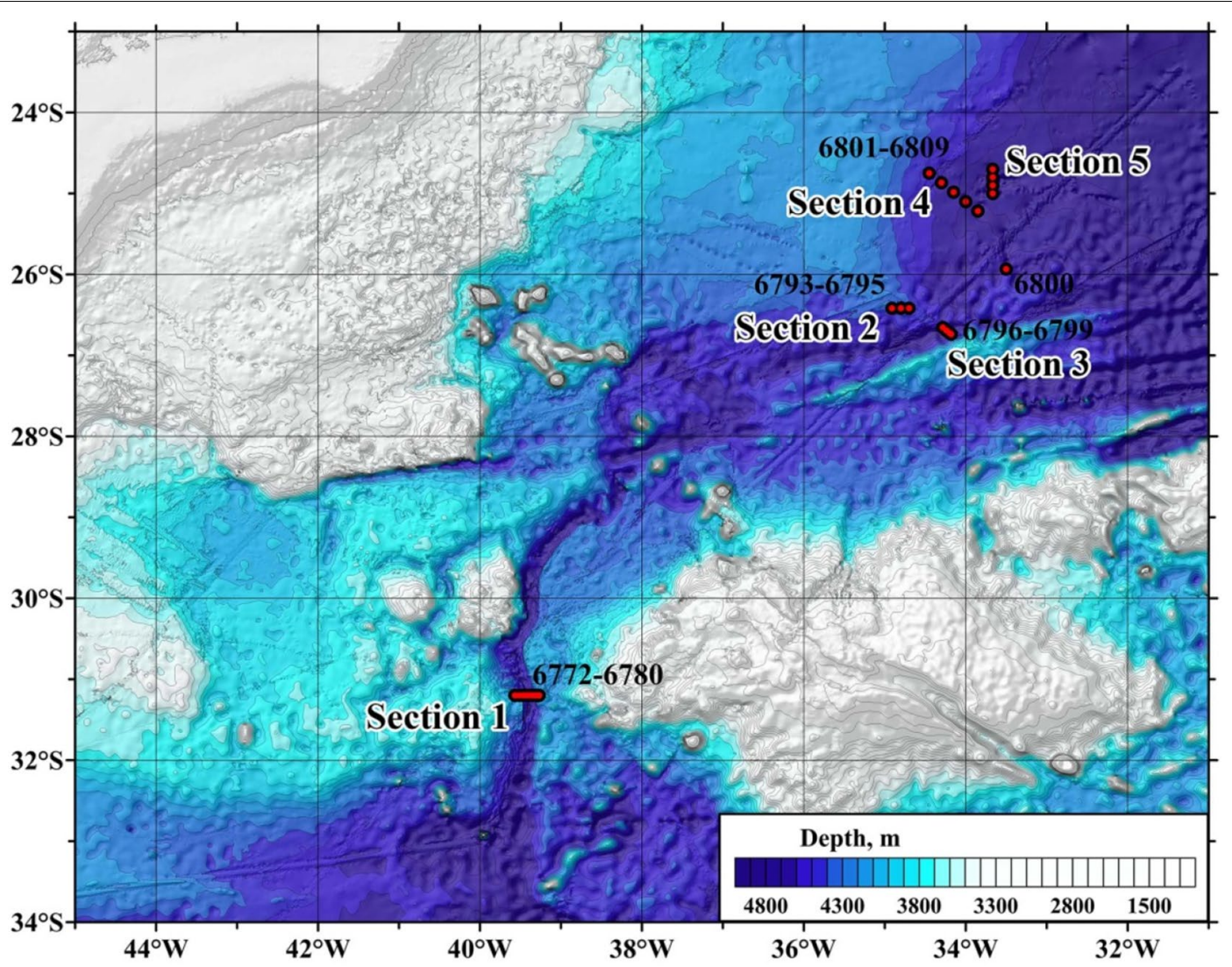

Fig. 1 Topography of the Vema Channel and its continuation. The numbers of stations in 2020 are indicated

\section{Bottom topography and data}

The bottom topography based on satellite altimetry (GEBCO 2019) was used as the basis of the topography chart. We corrected the depths over the routes of our vessels using echo sounders.

Our analysis is based on CTD/LADCP measurements (up to $5 \mathrm{~m}$ above the bottom) in 2003, 2009, 2010, 2012, 2013, 2018, 2019, and 2020 conducted in the region of the outflow of AABW from the Vema Channel and also on the data of the WOCE A17 (WHP 2002) section and quasi-zonal sections A09 in 2009 and 2018 along $24^{\circ} \mathrm{S}$ (https://cchdo.ucsd.edu). We also used the data of several stations from the WOD18 database. The locations of our and historical stations are shown in Fig. 2. The barotropic tide was removed from the resulting velocity profiles using the TPXO 9 model (Egbert and Erofeeva 2002).

\section{Result}

The data of CTD/LADCP sections in 2020 across the Vema Channel in the northern part of its extension demonstrate (Fig. 3) the existence of two coldest AABW flows $\left(\theta<0.2{ }^{\circ} \mathrm{C}\right)$. Repeated data since 2006 over the section across the Vema Channel at $31^{\circ} \mathrm{S}$ confirm this. One jet of
AABW follows the deep channel bed of the Vema Channel. It is shown in Fig. 3 that the deepest core of the current is located at depths of 4700-400 m. Another jet of $\mathrm{AABW}$ was found over the gentle northwestern slope of the channel (Fig. 3). The core of the current with highest velocities was located at a depth of 4100-4200 m (150 m above the bottom) and approximately $600 \mathrm{~m}$ shallower than the core of the deeper jet of AABW.

Both cores are shown in Fig. 3 over sections 2 and 3 $\left(26^{\circ} 30^{\prime}-27^{\circ} 00 \mathrm{~S}\right)$ in 2020 . The western section 2 does not fully show the upper jet, because we had to stop the casts in stormy weather. Section 2 was made along $26^{\circ} 25.0^{\prime} \mathrm{S}$ on April 3, 2020. The maximum velocity was recorded at the eastern station 6795 at $25^{\circ} 25.0 \mathrm{~S}, 34^{\circ}$ $41.9^{\prime} \mathrm{W}(12 \mathrm{~cm} / \mathrm{s})$. On December 31, 2019 we made two stations along $26^{\circ} 20.0^{\prime} \mathrm{S}$ at $34^{\circ} 30.0^{\prime} \mathrm{W}$ and $34^{\circ} 40.0^{\prime} \mathrm{W}$. The velocity in the bottom layer at the western station was directed to the northeast with a maximum of $9 \mathrm{~cm} / \mathrm{s}$ at $130 \mathrm{~m}$ above the bottom. Velocity at the bottom at the eastern station was lower, $6-7 \mathrm{~cm} / \mathrm{s}$. Thus, the maximum velocities at $25^{\circ} 20^{\prime} \mathrm{S}$ are close to $34^{\circ} 32^{\prime} \mathrm{W}$ longitude. This jet can be traced based on the coldest water at the bottom and maximum velocities generally directed to 


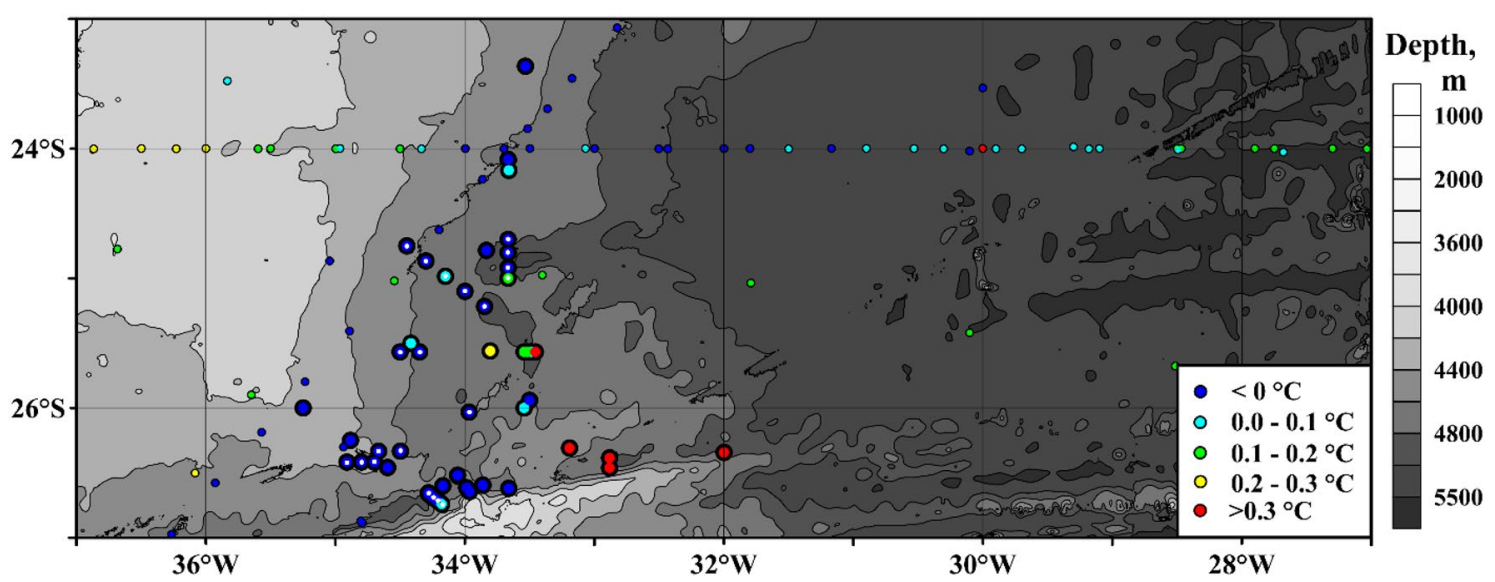

Fig. 2 Bathymetry of the study region north of the Vema Channel based on (GEBCO 2019). Locations of our CTD/LADCP casts in 2003-2020 (large circles) and historical stations (small circles) are shown. The corresponding potential temperatures at the bottom (5-20 $\mathrm{m}$ above the bottom) are shown in color. Stations in December 2019 and March-April 2020 are indicated with a white dot in the middle

the north and northeast on several sections in the study region (Figs. 7, 8).

\section{Discussion}

Let us consider the deeper current near the outflow of AABW from the Vema Channel based on our CTD/ LADCP casts in 2010-2020. The locations of the casts are in the region $26^{\circ} 30-26^{\circ} 50 \mathrm{~S}, 33^{\circ} 30-34^{\circ} 20 \mathrm{~W}$ (Fig. 4). The minimum potential temperature of this type of AABW in the northern region of the channel $\left(26^{\circ} 43.2^{\prime}\right.$ $\left.\mathrm{S}, 34^{\circ} 12.1^{\prime} \mathrm{W}\right)$ was recorded in $2003\left(\theta=-0.094^{\circ} \mathrm{C}\right)$. It is noteworthy that there is a positive trend in the bottom potential temperature with time (Zenk and Morozov 2007). Potential temperature at the bottom at the same point in 2020 was $\theta=-0.067{ }^{\circ} \mathrm{C}$. The measurements showed that the continuation of the coldest $\mathrm{AABW}$ flow splits into two bottom jets. One of the jets $\left(\theta=-0.087^{\circ} \mathrm{C}\right.$ in 2012) was directed initially to the east with a slight deviation to the northeast. The second jet with warmer water $\left(\theta=-0.063^{\circ} \mathrm{C}\right.$ in 2012) was directed almost to the north. The flow is confined to the feet of higher mountains, while on the outer side of the flow there is a flatter elevation, and the channel is $\sim 200 \mathrm{~m}$ deeper than the elevation; approximate width is $\sim 10 \mathrm{~km}$.

We searched for the continuation of the coldest AABW flow to the northeast of the channel. The stations were made in a quasi-zonal valley nearly at $26^{\circ} 30^{\prime} \mathrm{S}$ east of $33^{\circ}$ $30^{\prime} \mathrm{W}$, which seemed to be a topographic continuation of the Vema Channel (Fig. 3). We did not find potential temperatures below zero at the bottom there, despite the fact that the sill depth at $33^{\circ} 30^{\prime} \mathrm{W}$ is slightly shallower than $4500 \mathrm{~m}$. The vertical temperature gradient at the bottom $\left(0.46^{\circ} / 50 \mathrm{~m}\right)$ west of this sill is very high so that potential temperature at station $2527\left(26^{\circ} 37.2^{\prime} \mathrm{S}, 33^{\circ} 39.6^{\prime} \mathrm{W}\right)$ at a distance of $50 \mathrm{~m}$ above the bottom is $\theta \sim 0.4{ }^{\circ} \mathrm{C}$ (Fig. 5) unlike $\theta=-0.035{ }^{\circ} \mathrm{C}$ at the bottom $(4554 \mathrm{~m})$. The flow with potential temperatures below $0.2^{\circ} \mathrm{C}$ is confined to a bottom layer $40 \mathrm{~m}$ thick. The coldest continuation of the flow turns to the north because of the existence of this barrier.

Along with the eastward continuation of the AABW flow in the Vema Channel there is also a branch of this stream directed to the north (approximately along $34^{\circ}$ W). The northern channel is about $70 \mathrm{~m}$ deeper than the relatively flat plain in the west. Thermohaline properties of water in both smaller channels are similar to those in the Vema Channel.

The CTD/LADCP measurements in this channel revealed a northerly current with a velocity of approximately $5 \mathrm{~cm} \mathrm{~s}^{-1}$. The water in this current is characterized by the thermohaline properties similar to the water in the Vema Channel although it was slightly warmer $\left(-0.063{ }^{\circ} \mathrm{C}\right.$ in 2012$)$ compared to the potential temperature $\left(-0.087^{\circ} \mathrm{C}\right.$ in 2012$)$ measured in the eastward flow.

A zonal section of four stations was occupied in 2018 along $33^{\circ} 30^{\prime} \mathrm{W}$ nearly at $25^{\circ} 34^{\prime} \mathrm{S}$, where a small channel was found based on the digital database (GEBCO 2019). The channel is approximately $150-200 \mathrm{~m}$ deep relative to the surrounding plateau $(4700 \mathrm{~m})$ (Fig. 6). This channel is apparently the continuation of the bottom flow that turned to the north at $33^{\circ} 30^{\prime} \mathrm{W}$. The width of the channel here is about $7 \mathrm{~km}$ at a level of the $4800 \mathrm{~m}$ isobath, the maximum depth is $4950 \mathrm{~m}$. Echo-sounder measurements confirmed the existence of this small channel. The measurements of the velocity component along this channel show the presence of a high-speed (more than $35 \mathrm{~cm} \mathrm{~s}^{-1}$ ) northward velocity core of the bottom flow approximately 100-150 m 


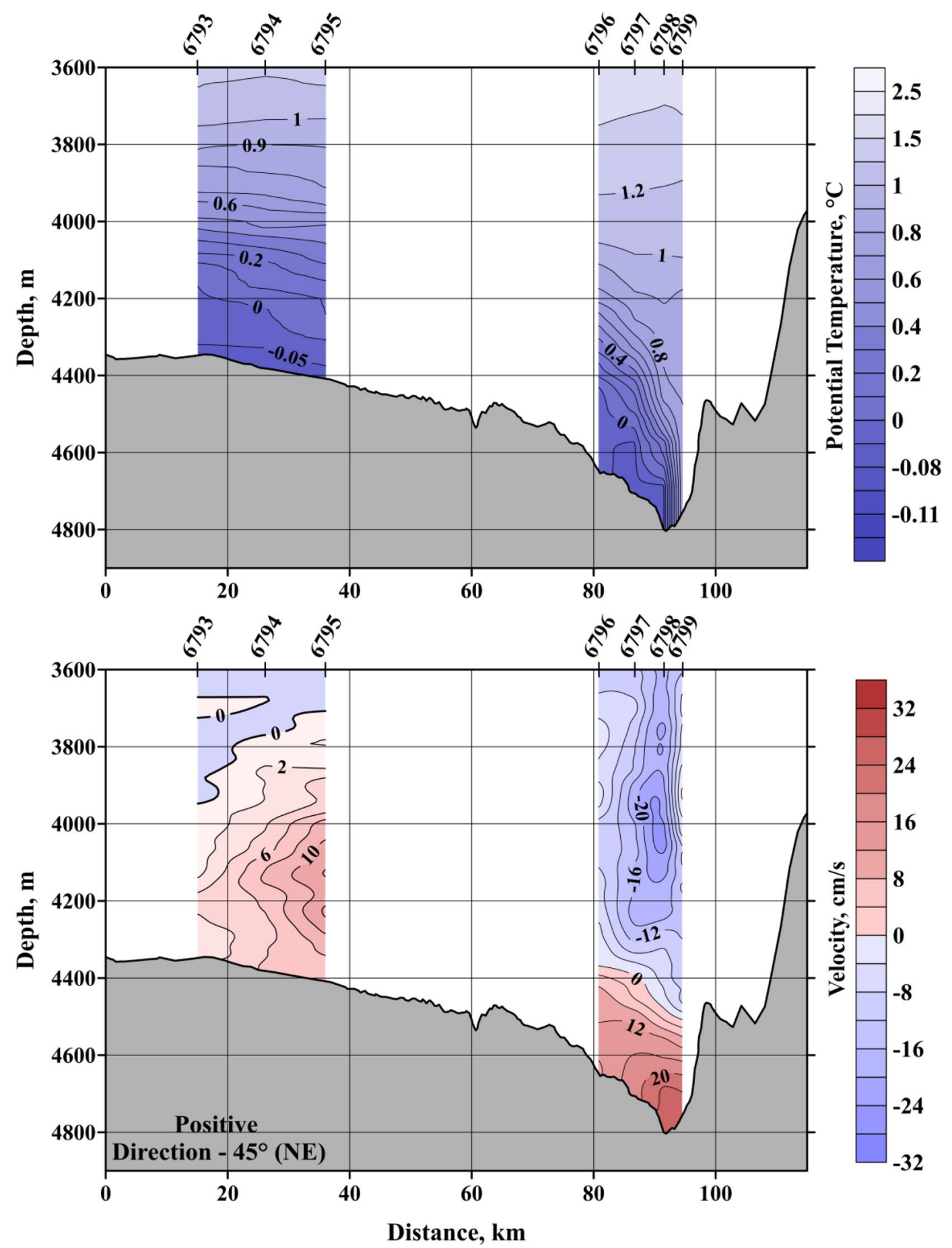

Fig. 3 Sections 2 (western) and 3 (eastern) (see Fig. 1) of potential temperature (top panel) and velocity (bottom panel) across the northern part of the Vema Channel along $26^{\circ} 30^{\prime}-27^{\circ} 00 \mathrm{~S}$ in April 2020. Numbers of stations are shown along the top axis

thick (Figs. 6, 4 in (Tarakanov et al. 2020)). Potential temperature of the bottom water in this channel was higher than zero. This layer with high velocities is located approximately below the $\theta=0.62{ }^{\circ} \mathrm{C}$ isotherm.
We estimated the transport in the bottom layer below $\theta<0.62{ }^{\circ} \mathrm{C}$ as $0.150 \pm 0.007 \mathrm{~Sv}$. This transport of bottom water is more than one order of magnitude smaller than the estimates of the total AABW flow across the 


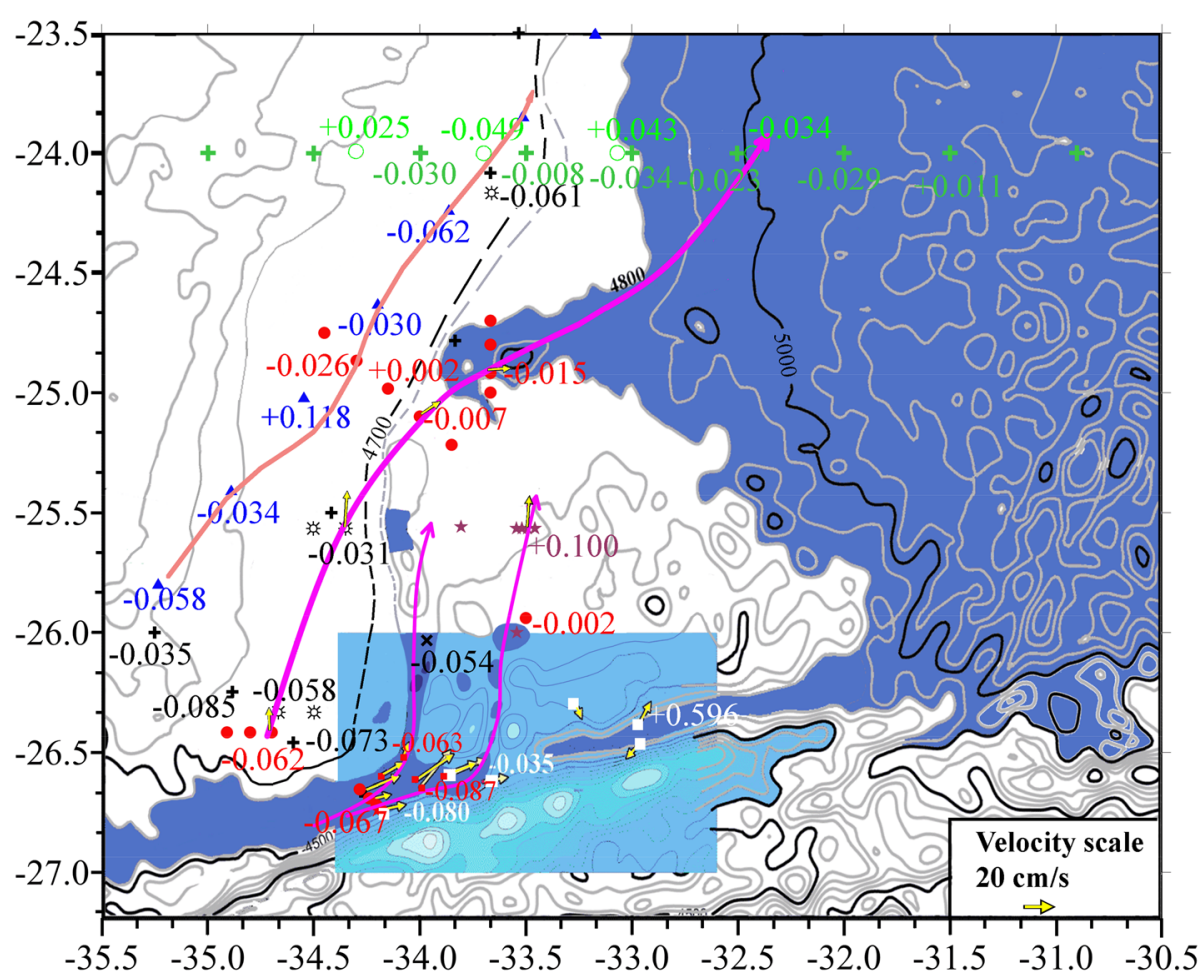

Fig. 4 Bathymetry of the study region based on (GEBCO 2019) and corrected with our echo-sounder measurements in 2010-2020. Locations of CTD/LADCP casts are shown. Blue triangles show the stations of the WOCE A17 section in 1994.Black crosses (+) show our stations in 2003. Black cross $(x)$ shows the station in 2009. Green circles show stations of the A09 (24ㅇ) section in 2009 and green crosses show the A09 stations in 2018. Small red squares are our stations in 2012. Larger white squares are our stations in 2013. Violet stars show our stations in 2018. Circles with rays (B\&W) show stations in 2019. Red circles show stations in 2020. Yellow arrows show the directions of currents and their velocity (vectors). Numbers in color at the dots of stations (the same color) indicate potential temperature at the bottom. Blue colors show deep water regions, especially the canyon at $24^{\circ} 40^{\prime} \mathrm{S}$. The blue rectangle shows a region, which was studied best of all in 2010-2020. The magenta lines show a scheme of the pathways of AABW. The beige line shows the pathway of a shallow jet based on CTD data in 1994 and 2003. Dashed lines show isobaths 4700 and $4750 \mathrm{~m}$ based on our echo-sounder measurements

section at $31^{\circ} \mathrm{S}$. As usual in the Vema Channel, the core of cold fresher water is displaced to the eastern slope (i.e., to the right of the flow direction) with the formation of the sharpest deep thermocline over it (Jungclaus and Vanicek 1999). This displacement is also shown in Fig. 3 over the section in the northern part of the Vema Channel.

The difference in the temperature profiles along the meridional channel (Fig. 5) shows gradual deepening of the isotherms (up to $\sim 400 \mathrm{~m}$ ) in the bottom layer from the Vema Channel Extension (station 2496; $26^{\circ} 31.1$ $\mathrm{S}, 34^{\circ} 03.3 \mathrm{~W}$ ) to the section (station 2710 at $25^{\circ} 34^{\prime} \mathrm{S}$, $33^{\circ} 29.5 \mathrm{~W}$ ) especially notable in the layer colder than $0.60-0.65{ }^{\circ} \mathrm{C}$. This small channel is a continuation of the deepest bed of the Vema Channel. As the bottom flow propagates to the north its temperature increases and the thickness of the layer decreases, which leads to a decrease in the transport of coldest water. It is likely that this flow eventually disappears. Potential temperature of the flow at $25^{\circ} 30 \mathrm{~S}$ becomes higher than zero.
The pathway of the upper cold AABW flow is located over the western slope of the Vema Channel. Such an isolated core over the western terrace of the Vema Channel found on the repeated section (along $31^{\circ} 12^{\prime} \mathrm{S}$ ) was observed in the potential temperature distributions in $1984\left(-0.15{ }^{\circ} \mathrm{C}\right), 1991\left(-0.16{ }^{\circ} \mathrm{C}\right), 1992\left(-0.13{ }^{\circ} \mathrm{C}\right)$, $2006\left(-0.10{ }^{\circ} \mathrm{C}\right), 2009\left(-0.10^{\circ} \mathrm{C}\right), 2017\left(-0.06{ }^{\circ} \mathrm{C}\right), 2018$ $\left(-0.08{ }^{\circ} \mathrm{C}\right)$, and $2020\left(-0.06^{\circ} \mathrm{C}\right)$. Velocity measurements performed since 2006 confirm the existence of this core; they range within $30-36 \mathrm{~cm} \mathrm{~s}^{-1}$ (Morozov et al. 2010).

In 2009, a CTD-section along $24^{\circ} \mathrm{S}$ was occupied by British scientists. The section was repeated in 2018 (https ://cchdo.ucsd.edu). In 2009, two individual cores of low bottom temperatures were found on this section with potential temperatures in the first core ranging between $-0.04{ }^{\circ} \mathrm{C}$ and $-0.05^{\circ} \mathrm{C}$ at $33^{\circ} 50^{\prime} \mathrm{W}$ (approximately at a depth of $4650 \mathrm{~m}$ ) and in the second core at $31^{\circ} 25^{\prime} \mathrm{W}$ (in the depth range 5000-5200 $\mathrm{m}$ ) the potential temperatures were between $-0.03{ }^{\circ} \mathrm{C}$ and $-004{ }^{\circ} \mathrm{C}$. These cores slightly displaced in 2018. Potential temperatures in the 


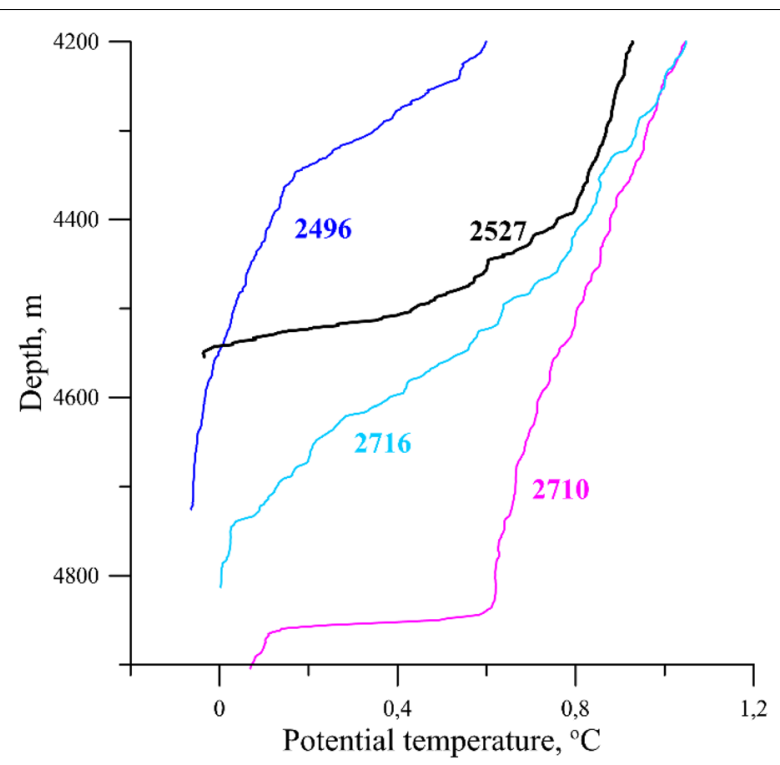

Fig. 5 Profiles of potential temperature below $4200 \mathrm{~m}$ at stations 2496 ( $26^{\circ} 31.1^{\prime}$ S, $34^{\circ} 03.3^{\prime}$ W), 2710 ( $25^{\circ} 34.0^{\prime}$ S, $33^{\circ} 29.5^{\prime}$ W), 2527 $\left(26^{\circ} 37.2^{\prime} \mathrm{S}, 33^{\circ} 39.6^{\prime} \mathrm{W}\right)$, and $2716\left(26^{\circ} 00.0^{\prime} \mathrm{S}, 33^{\circ} 32.5^{\prime} \mathrm{W}\right)$ in the depressions (see Fig. 4)

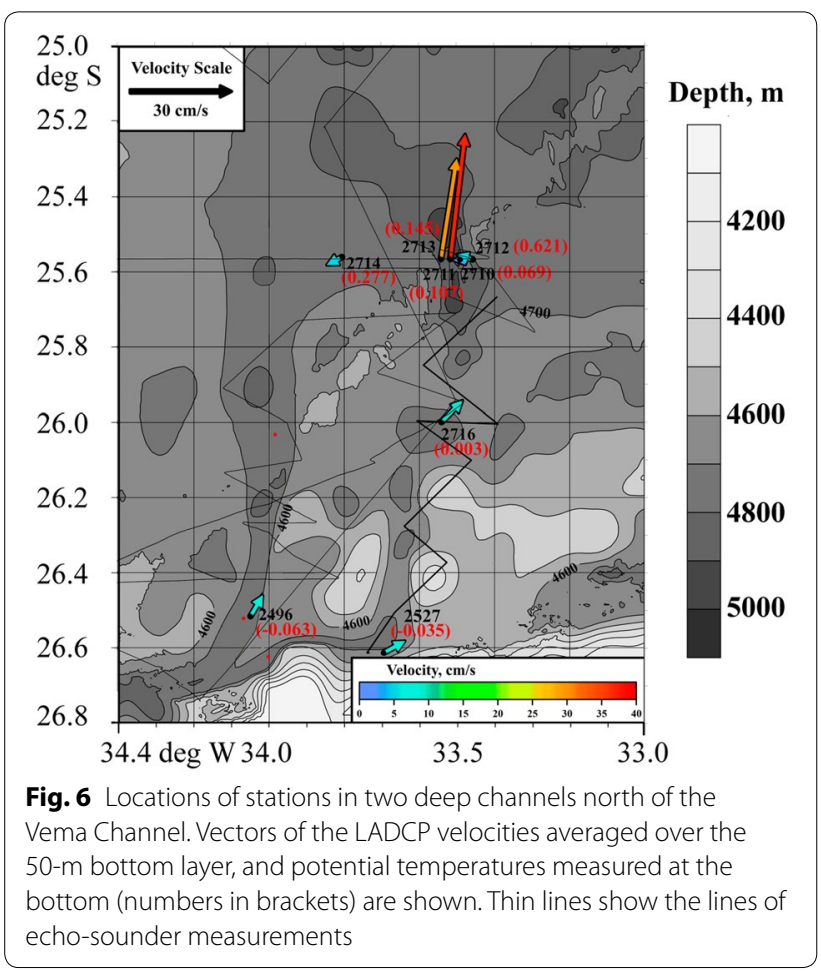

cores in 2018 were approximately $-0.03^{\circ} \mathrm{C}$. The potential temperature section along this line in $2018\left(24^{\circ} \mathrm{S}\right)$ is shown in Fig. 7.
It is clear that the two deeper jets considered above could not have such a cold continuation at $24^{\circ} \mathrm{S}$, because the upper core at $24^{\circ} \mathrm{S}$ was located at shallower depths $(\sim 4600 \mathrm{~m})$ than the two deeper continuation flows $(\sim 4700 \mathrm{~m})$ from the deep Vema Channel bed. The potential temperature of the cold water found at $24^{\circ} 00^{\prime} \mathrm{S}, 33^{\circ}$ $42^{\prime} \mathrm{W}$ at a depth of $4600 \mathrm{~m}$ was $-0.049{ }^{\circ} \mathrm{C}$ in 2009 . In 2018 the potential temperature increased to $-0.029^{\circ} \mathrm{C}$. The lower core at $24^{\circ} \mathrm{S}$ was much colder $\left(-0.03^{\circ} \mathrm{C}\right)$ than the two deeper jets of the continuation of AABW flow from the deep channel bed. Potential temperature at $25^{\circ}$ $30 \mathrm{~S}$ ranged within $0.069^{\circ}-0.145^{\circ} \mathrm{C}$ above zero (Fig. 6).

It is likely that regions of relatively cold bottom temperature (at $24^{\circ} \mathrm{S}$ ) could be associated with the continuation of the upper current of AABW from the Vema Channel that was initially spreading above the western wall of the channel. There is no other source of such cold water, because the potential temperature of bottom water in the two channels continuing the Vema Channel bed is not as cold as the one recorded on the $24^{\circ} \mathrm{S}$ section. The measurements in 2009 and 2018 at $24^{\circ} \mathrm{S}$ were made at a distance of $300 \mathrm{~km}$ north of the channel. The inclination of the slope in this region is rather small: approximately 1:100. A jet of cold water in motion can maintain its position above such a slope. Shallow depressions on the continental slope $(\sim 50-100 \mathrm{~m})$ were found exactly in the region of the location of cold-water cores, which could be eroded by the bottom water flow. We emphasize that there are no sources of such cold water other than the Vema Channel. Hence, this water arrives here with the upper jet of AABW. In 2018, 2019, and 2020 we made stations to locate the upper jet north of the Vema Channel based on the existence of cold temperatures and direction of the flow with a northerly component. We confirmed its location at a latitude of $25^{\circ} 34^{\prime} \mathrm{S}$ and on sections 4 and 5 around $25^{\circ} \mathrm{S}$ (Figs. 1, 8, 9). We also found this jet in the southern region closer to the Vema Channel at $26^{\circ} 20^{\prime} \mathrm{S}, 34^{\circ} 30^{\prime} \mathrm{W}$.

The jet that follows over the western slope of the Vema Channel was traced based on the low potential temperatures and vectors of velocity at the bottom shown with yellow arrows in Fig. 4. In 2020, we made two CTD/ LADCP sections (Figs. 8, 9) to show that this bottom flow is directed into the canyon, which is shown in Fig. 4. A zonal canyon is located at $24^{\circ} 45^{\prime} \mathrm{S}$; the canyon becomes wider approximately at $33^{\circ} 00^{\prime} \mathrm{W}$. As seen from the distribution of temperature at the bottom from the historical data set (Fig. 2), this canyon diverts part of the flow of the coldest AABW down the slope.

We could detect this jet in 2020 by the maximum velocities and low temperatures at $26^{\circ} 25^{\prime} \mathrm{S}, 26^{\circ} 20^{\prime} \mathrm{S}, 25^{\circ}$ $34^{\prime} \mathrm{S}, 25^{\circ} 06^{\prime} \mathrm{S}$, and $24^{\circ} 55^{\prime} \mathrm{S}$ (Fig. 4). At the latter point the jet descends down the canyon. The $\theta$, S-curves based 


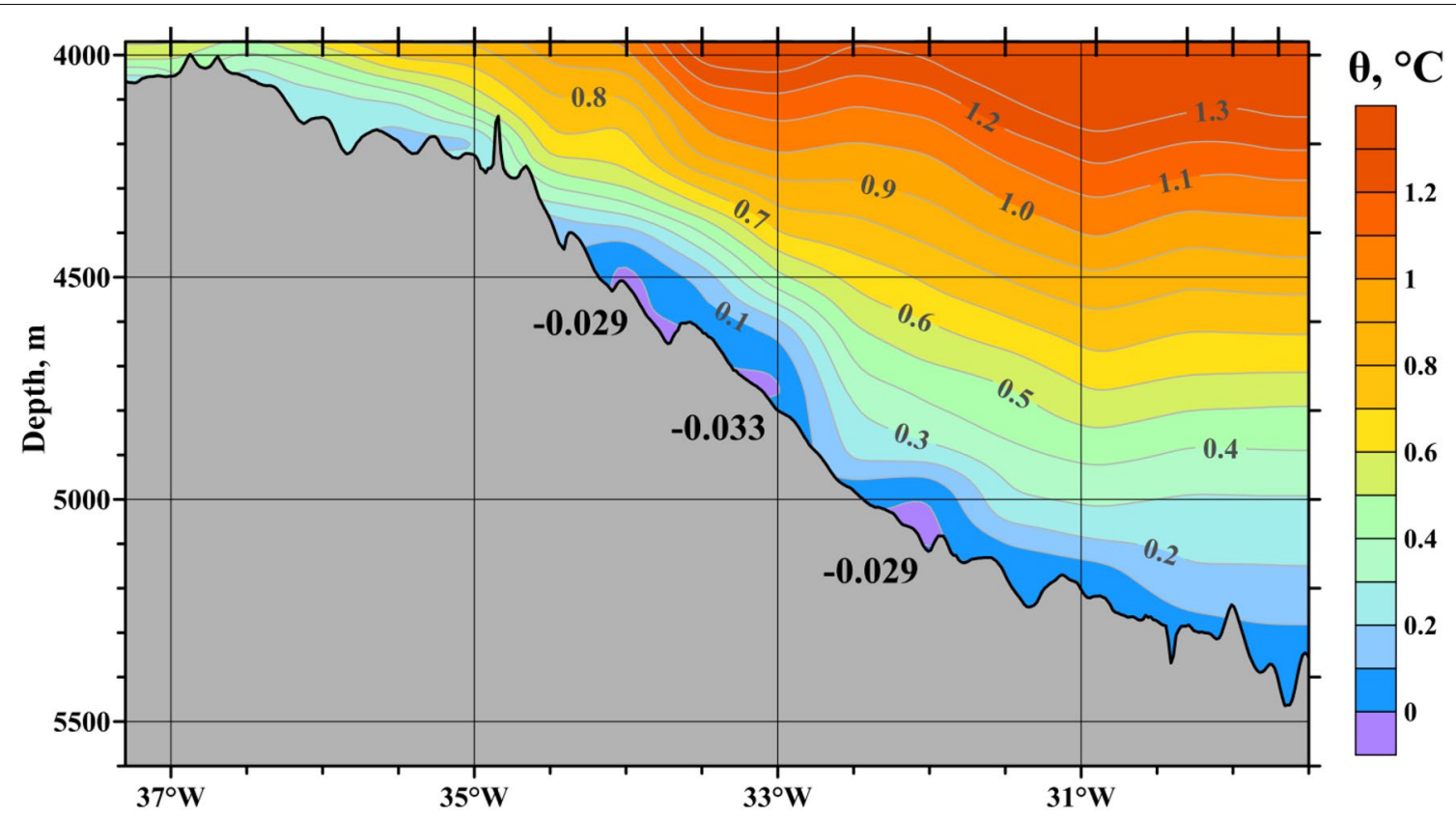

Fig. 7 Distribution of potential temperature $\theta$ above the bottom part of the A09 section (2018) over the slope of South America along $24^{\circ} \mathrm{S}$. Potential temperatures in the cold cores at the bottom are indicated

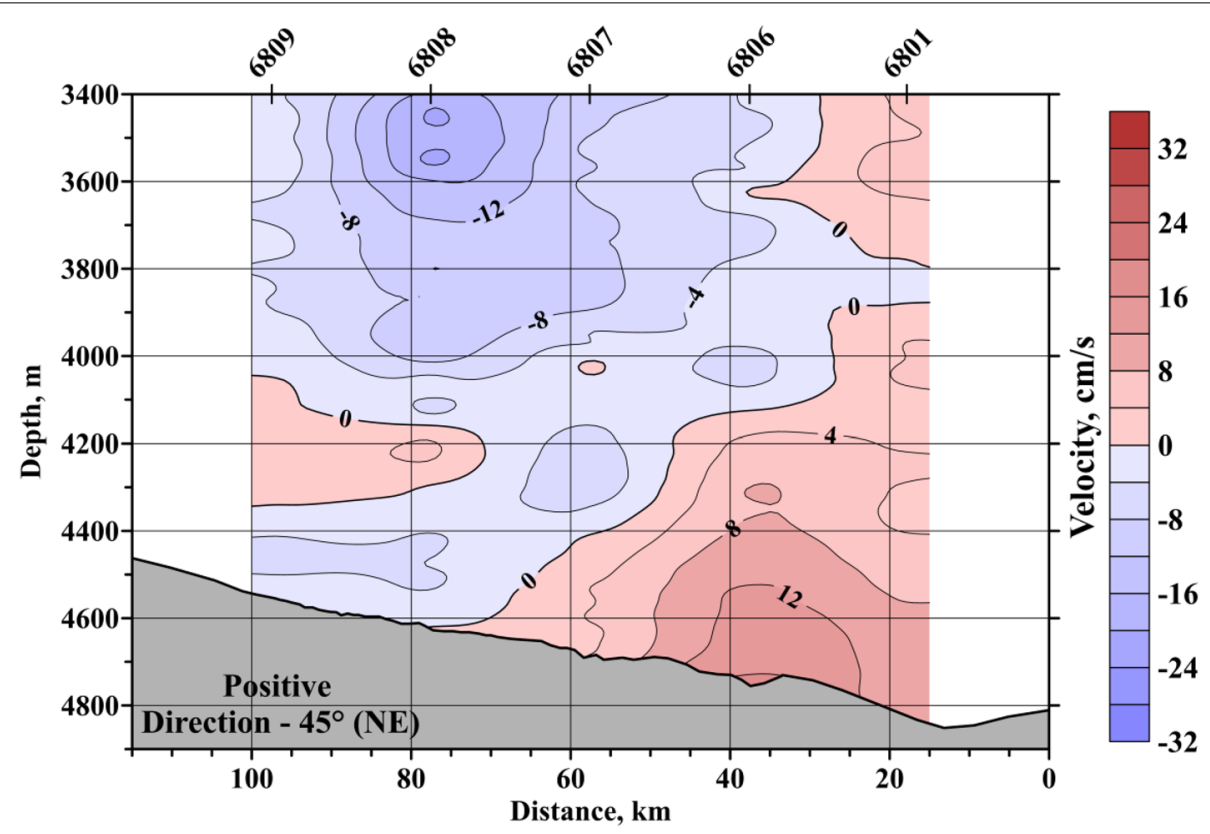

Fig. 8 Section 4 (Fig. 1) of velocity north of the Vema Channel

on the data in 2020 at several points of the pathway are shown in Fig. 10. The curves shown in the figure are very close.

It is not likely that this jet splits and part of the flow goes to the north, because in this case, the flow should go upslope. We analyzed the bottom topography from the digital databases GEBCO and ETOPO and our ecosounder data in the region. The 4700 isobath is actually located approximately $50 \mathrm{~km}$ to the southeast relative to its position that can be plotted from the digital data. Based on our echo-sounder data we plotted isobaths 4700 and 4750 with dashed lines in Fig. 4. 


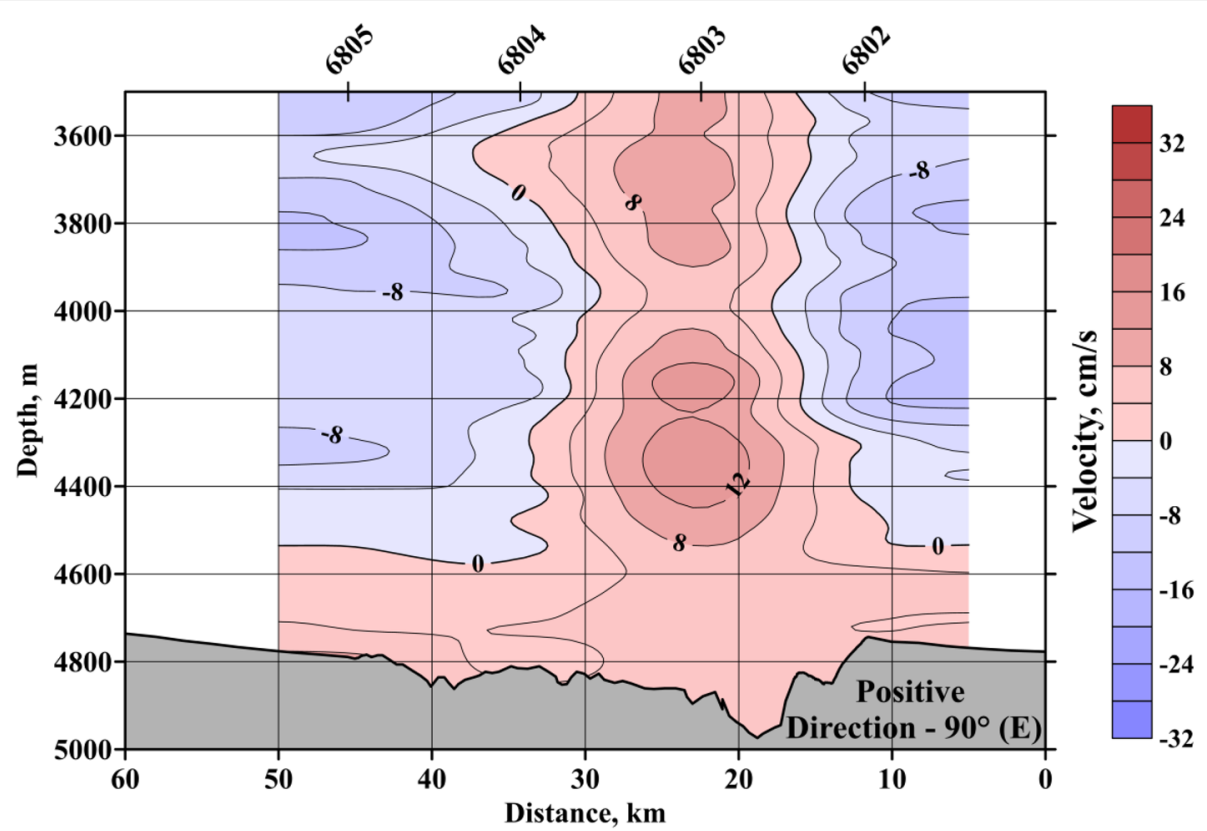

Fig. 9 Section 5 (see Fig. 1) of velocity north of the Vema Channel across the canyon

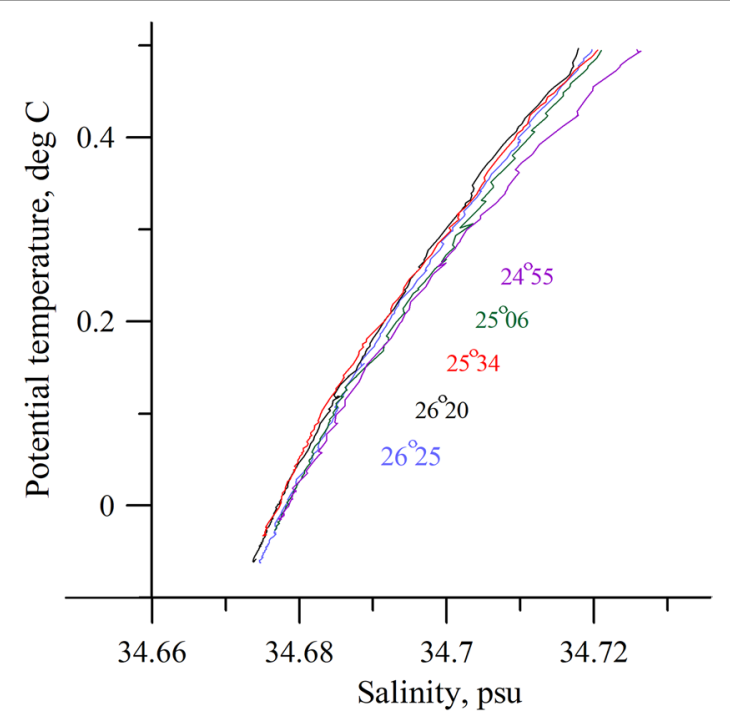

Fig. 10 Graphs of $\theta$, S-relations along the pathway of the upper jet. Latitudes of the points are indicated on the graph with the same color as the curves

We conclude that the coldest type of AABW $\left(\theta<0.0{ }^{\circ} \mathrm{C}\right)$ flows north from the Vema Channel as two jets, one of which is located in the deep channel bed and the other approximately $200 \mathrm{~m}$ above the western slope of the channel. The deep channel bed of the Vema Channel does not end in the region $26^{\circ} 40^{\prime} \mathrm{S}, 34^{\circ}$ $00^{\prime} \mathrm{W}$ but continues as a widening to the north in the Brazil Basin. This flow generally diverges into two bottom flows along smaller channels. The potential temperature of the flow increases in the course of water spreading. Approximately at $25^{\circ} 30^{\prime} \mathrm{S}$, the potential temperature in these flows becomes warmer than $0{ }^{\circ} \mathrm{C}$.

It is likely that a third jet exists at shallower depths. We could trace it based on the CTD casts in 1994 and 2003, which revealed potential temperatures below zero; however, there were no LADCP measurements. We plotted this jet with a beige line. This line is drawn close to the points of stations with cold potential temperatures. The station with potential temperature $+0.118^{\circ} \mathrm{C}$ is located over an elevation and we have drawn the line deeper. This jet continues to the north, and can be seen in Fig. 7 as the upper cold core at $24^{\circ} \mathrm{S}$. It is not reasonable to compare the $\theta, \mathrm{S}$-curves from the data of different years $(1994,2003,2009,2018)$, because the properties of AABW fluctuate as shown in our book (Morozov et al. 2010).

The potential temperature of the upper jet remains below zero even at $24^{\circ} \mathrm{S}$. Measurements north of this latitude also revealed negative potential temperatures of the flow. This can be a continuation of the AABW jet described in (Sandoval and Weatherly 2001). Thus, we can construct a scheme for the continuation of the $\mathrm{AABW}$ flow from the Vema Channel based on our and historical measurements (Fig. 4). 


\section{Conclusions}

The most important result of our field works in the region of $\mathrm{AABW}$ outflow from the Vema Channel is that there are two outflowing jets. The existence of even shallower third jet can be seen only from the CTD data.

The flow in the deep channel bed splits into two parts, one of which turns to the north and the second continues in the eastern direction but also turns to the north, because it cannot overflow a barrier at $33^{\circ} 30^{\prime} \mathrm{W}$. The thickness of both flows decreases and the temperature increases so than they disappear approximately at $25^{\circ} 30^{\prime}$ $\mathrm{S}$.

The upper jet that initially flows above the western slope of the channel spreads further to the north than the bottom flows in the small channels. Hence, this is exactly the jet that transports $\mathrm{AABW}$ farther to the north and fills the deep basins in the North Atlantic.

\section{Acknowledgements}

We thank the crews of R/V "Akademik Sergey Vavilov" for their help in our research and measurements in the ocean.

\section{Authors' contributions}

EM, DF, and RT participated together in many cruises. All three participated in field measurements and data analysis. EM was head of the expeditions and wrote the text consulting both co-authors. All authors read and approved the final manuscript.

\section{Funding}

This research was supported by the state assignment of Russia No. 0149-20190004 and Russian Foundation for Basic Research (Grant 20-08-00246).

\section{Availability of data and materials}

Field data set for this research is available from PANGAEA Data Archiving \& Publications (https://doi.pangaea.de/10.1594/PANGAEA/903812).

\section{Competing interests}

The authors claim that they do not have any conflict of interest.

Received: 22 July 2020 Accepted: 17 October 2020

Published online: 29 October 2020

\section{References}

Egbert GD, Erofeeva S (2002) Efficient inverse modeling of barotropic ocean tides. J Atmos Ocean Tech 19:183-204. https://doi.org/10.1175/15200426(2002)019\%3c0183:EIMOBO\%3e2.0.CO;2

Frey DI, Morozov EG, Fomin VV, Diansky NA, Tarakanov RY (2019) Regional modeling of Antarctic Bottom Water flows in the key passages of the Atlantic. J Geophys Res Oceans 124:8414-8428. https://doi. org/10.1029/2019JC015315

GEBCO Bathymetric Compilation Group 2019 (2019). The GEBCO 2019 Grid - a continuous terrain model of the global oceans and land. British Oceanographic Data Centre, National Oceanography Centre, NERC, UK. doi:10/ c33m. doi:10.5285/836f016a-33be-6ddc-e053-6c86abc0788e

Hogg N, Siedler G, ZenkW (1999) Circulation and variability at the southern boundary of the Brazil Basin. J PhysOceanogr 29:145-157

Jungclaus J, Vanicek M (1999) Frictionally modified flow in a deep ocean channel: application to the vema channel. J Geoph Res 104(C9):21123-21136. https://doi.org/10.1029/1998jc900055

Morozov EG, Demidov AN, Tarakanov RY, Zenk W (2010) Abyssal Channels in the Atlantic Ocean: Water Structure and Flows. Springer, Dordrecht. https ://doi.org/10.1007/978-90-481-9358-5

Sandoval FJ, Weatherly GL (2001) Evolution of the deep western boundary current of Antarctic Bottom Water in the Brazil Basin. J PhysOceanogr 31:1440-1460. https://doi.org/10.1175/1520-0485(2001)031\%3c144 0:EOTDWB\%3e2.0.CO:2

Speer KG, Zenk W (1993) The flow of Antarctic Bottom water into the Brazil Basin. J PhysOceanogr 23:2667-2682

Tarakanov RY, Morozov EG (2015) Flow of Antarctic Bottom Water at the output of the Vema Channel. Oceanology 55:153-161. https://doi. org/10.1134/S0001437015010166

Tarakanov RY, Morozov EG, Frey DI (2020) Hydraulic continuation of the abyssal flow from the Vema Channel in the southwestern part of the Brazil Basin. J Geophys Res 125:e2020JC016232. https://doi.org/10.1029/2020JC0162 32

WHP (2002) WOCE Hydrographic Programme, WHP (2002): Physical oceanography during Maurice Ewing cruise 3230CITHER2_1 on section A17C. PANGAEA. https://doi.org/10.1594/PANGAEA.293955

Zenk W, Morozov EG (2007) Decadal warming of the coldest Antarctic Bottom Water flow through the Vema Channel. Geophys Res Lett 34:L14607. https://doi.org/10.1029/2007GL030340

\section{Publisher's Note}

Springer Nature remains neutral with regard to jurisdictional claims in published maps and institutional affiliations.

\section{Submit your manuscript to a SpringerOpen ${ }^{\circ}$ journal and benefit from:}

- Convenient online submission

- Rigorous peer review

- Open access: articles freely available online

- High visibility within the field

- Retaining the copyright to your article

Submit your next manuscript at $\boldsymbol{\nabla}$ springeropen.com 